\title{
PENGEMBANGAN KAWASAN AGROWISATA TERPADU DI PANTAI MALANG SELATAN DALAM MENDUKUNG SEGITIGA EMAS WISATA (BATU, BROMO, MALANG SELATAN)
}

\author{
Agung Sugeng Widodo $^{{ }^{*}}$, Susinggih Wijana ${ }^{2}$, Ary Mustofa Ahmad ${ }^{1}$ \\ ${ }^{1}$ Jurusan Teknik Mesin, Fakultas Teknik, Universitas Brawijaya, Malang, Indonesia \\ ${ }^{2}$ Jurusan Teknologi Industri Pertanian, Fakultas Teknologi Pertanian, Universitas Brawijaya, Malang, Indonesia \\ *Penulis Korespodensi: agung.swd@gmail.com
}

\begin{abstract}
Abstrak
Desa Purwodadi merupakan desa yang memiliki wilayah pantai malang selatan. Pantai di desa ini menyuguhkan panorama alam yang indah disertai aktivitas nelayan dikampung nelayan. Akan tetapi, potensi yang ada belum optimal dikembangkan secara maksimal. Pantai ini cukup strategis karena berada di suatu wilayah segitiga emas yaitu kota Batu,wilayah Gunung Bromo, dan Wilayah Malang Selatan. Pengembangan wilayah ini diharapkan dapat menujang taraf ekonomi masyarakat disekitar wilayah segitiga emas dan mampu menunjang nama daerah. Program pengabdian ini menggunakan beberapa metode yaitu survei lokasi pengabdian, negosiasi mitra, penandatanganan nota kesepakatan kerjasama, pengurusan perizinan dengan pihak terkait, pelaksanaan program, dan evaluasi. Untuk langkah-langkah yang perlu dilakukan adalah 1) sosialisasi kepada masyarakat mengenai pentingnya agrowisata sehingga dapat menumbuhkan kesadaran masyarakat untuk berpartisipasi aktif dalam geliat wisata yang berbasis pada agro 2) Mengedukasi kelompok masyarakat tentang IPTEK 3) Mendampingi masyarakat dalam upaya untuk diversifikasi produk wisata berupa cinderamata dan kuliner. dari hasil kegiatan, disusun rencana pengembangan kuliner serta potensi lain yang dapat dikembangkan. Salah satu strategi yang digunakan untuk memperkenalkan serta mengangkat wisata kuliner dan wisata alam di wilayah ini dengan dibuatkannya brosur serta website. Selain itu, edukasi tentang pengelolaan website juga dilakukan kepada masyarakat untuk dapat mempromosikan wilayah ini sehingga dapat menciptakan ekonomi kerakyatan.
\end{abstract}

Kata Kunci: Desa Purwodadi, Pantai Malang Selatan, Wisata Kuliner, Wisata Alam,

\begin{abstract}
Purwodadi village is a village that has the southern poor coastal area. The beach in this village presents a beautiful natural scenery accompanied by fishing activities dikampung fishermen. However, the potential is not optimally developed optimally. This beach is quite strategic because it is located in a golden triangle region of Batu, Mount Bromo region, and South Malang region. The development of this region is expected to support the economic level of the community around the golden triangle region and able to support the name of the region. This devotional program uses several methods, namely surveying the location of dedication, negotiating partners, signing a memorandum of cooperation agreement, licensing arrangements with related parties, program implementation, and evaluation. For the steps that need to be done is 1) socialization to the public about the importance of agro tourism so that it can raise public awareness to participate actively in agro-based tourism geliat 2) Educate community groups about science and technology 3) Accompany the community in an effort to diversify tourism products in the form of souvenirs and culinary. from the results of activities, culinary development plans are developed and other potentials that can be developed. One of the strategies used to introduce and elevate culinary and nature tourism in the region with the creation of brochures and websites. In addition, education on website management is also done to the community to be able to promote this region so as to create a populist economy.
\end{abstract}

Keywords: Purwodadi Village, South Malang Beach, Culinary Tourism, Nature Tourism,

\section{PENDAHULUAN}

Desa Purwodadi adalah desa yang terletak di kabupaten Malang tepatnya pada kecamatan Tirtoyudo. Desa yang memiliki luas daerah sekitar $1041 \mathrm{Ha}$ ini dikenal dengan potensi pantainya yang memiliki keindahan alam yang belum banyak tercampur tangan manusia, hal ini dikarenakan akses menuju lokasi tersebut sulit dan medannya cukup berat jika ditempuh dengan jalur darat. Desa yang dikelilingi oleh bukit dan sebagai desa pesisir memiliki potensi yang tidak hanya datang dari lautnya saja, tetapi hasil alam desa ini juga 
mendukung perekonomian masyarakatnya. Seperti hasil kebunnya yaitu pisang, kopi, cengkeh, nilam dan hasil lautnya yang tinggi populasi ikan - ikan bernilai ekonomis. Indikasi potensi kegiatan didesa Purwodadi tidak terlalu mendukung untuk kegiatan perdagangan, hal ini dikarenakan posisi desa bukanlah jalur strategis untuk diadakannya perdagangan. Akan tetapi potensi yang paling banyak menghasilkan keuntungan berasal dari laut desa Purwodadi. Desa yang memiliki 8 teluk ini mampu dijadikan destinasi wisata air, seperti wisata pantainya, olahraga memancing, pariwisata sky air dan taman laut. Melihat begitu banyak potensi didesa maka diperlukannya sebuah pengkajian lebih dalam terhadap potensi desa yang belum disadari oleh masyarakat. Potensi desa yang belum tereskplor terutama pada hasil kebunnya jika disadari oleh masyarakat kemungkinan hasilnya akan menyeimbangi keuntungan potensi lautnya.

Melalui proses analisis ini diharapkan potensi yang belum digali dapat digali dan potensi yang sudah dijalankan dapat dikembangkan lebih baik lagi. Harapannya kedepannya potensi ini dapat dijadikan sebagai paket wisata ketika pengunjung mendatangi desa Purwodadi.

\section{BAHAN DAN METODE}

Pada pengabdian masyarakat ini, bahan yang digunakan hamper tidak ada karena proses pengumpulan data adalah melalui survey secara langsung. Metode yang digunakan yaitu survey langsung, wawancara, serta pembuatan website.

\section{HASIL DAN PEMBAHASAN}

I. Website

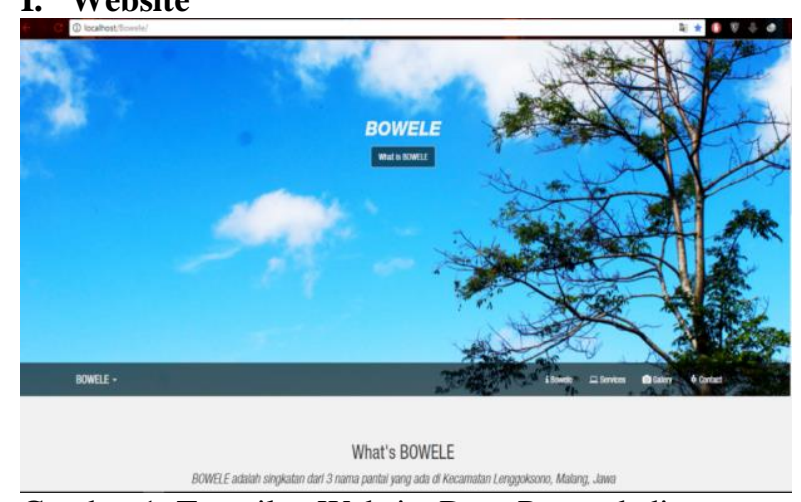

Gambar 1. Tampilan Website Desa Purwodadi

Situs BOWELE ini bertujuan untuk mempromosikan lokasi wisata BOWELE (Bolu-bolu, Wediawu, dan Lenggoksono) yang terletak di kecamatan Tirtoyudo, Malang. Diharapkan dengan adanya website ini para pengunjung/wisatawan maupun turis lebih mudah dalam mengakses serta mendapatkan informasi mengenai lokasi - lokasi wisata yang ada si Desa Purwodadi, dengan mudah mengetahui lokasi lokasi tempat tinggal yang dapat digunakan serta lokasi - lokasi foto yang bagus.

\section{Icon - icon Pariwisata \\ 1. Pantai Lenggoksono}
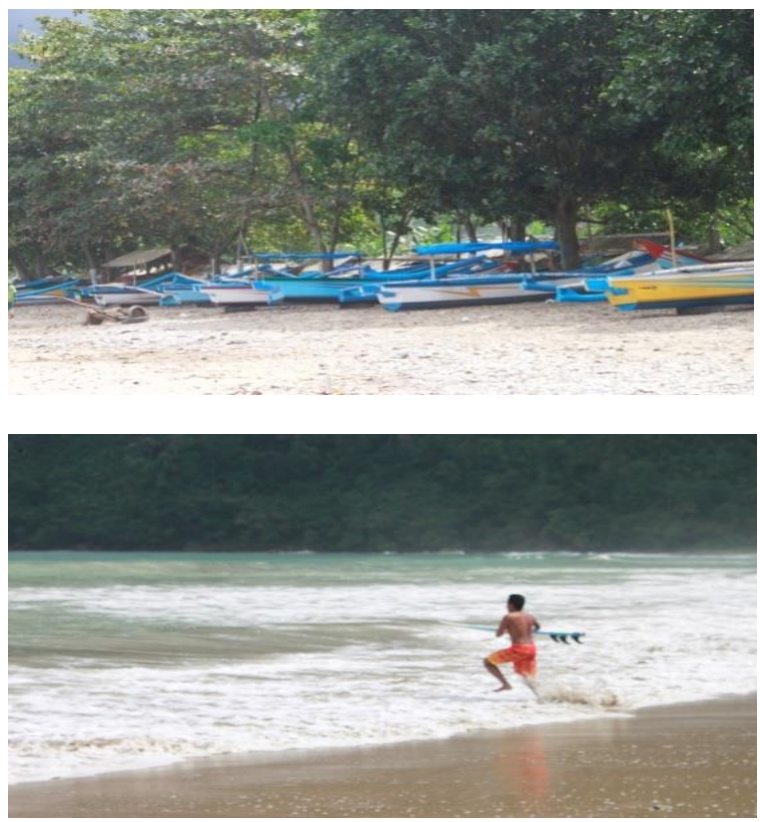

Gambar 2. Pantai Lenggoksono

Pantai Lenggoksono yang berada di desa Purwodadi merupakan pantai yang indah dan menarik untuk dikunjungi dengan jangkauan yang sangat mudah dari desa Purwodadi. Pada pantai Lenggoksono terdapat dua sungai pada bagian tepi barat dan tepi timur yang airnya menglir langsung ke laut sehingga terdapat daerah pertemuan air tawar dan air laut. Untuk akses masuk ke pantai Lenggoksono dapat ditempuh dengan jalur darat mengarah keselatan dari perkampungan desa Purwodadi. Biaya masuk ke pantai Lenggoksono yang sangat terjangkau, yaitu Rp 10.000 per orang, biaya parkir mobilnya seharga $\mathrm{Rp}$ 10.000 dan parkir motor seharga $\mathrm{Rp} 5.000$, biaya tersebut dapat di bayar di loket masuk pantai Lenggoksono.

Daerah bibir pantai lenggoksono banyak terdapat bebatuan alam dan juga pepohonan yang tinggi, perahu-perahu nelayan juga menghiasi di sepanjang bibir pantai serta warung-warung makan yang dapat di singgahi dan juga tersedia fasilitas kamar mandi yang berada disekitar warung-warung serta terdapat Mushola sebagai tempat beribadah. Keindahan pantai juga di dukung oleh para peselancar yang bermain dengan ombak sedang di pantai yang terkenal dengan tempat berlatih surfing dan sudah di sediakan tempat penyewaan papan surfing serta segala perlengkapannya, bahkan pada tanggal 16 bulan agustus diadakan lomba mancing mania di pantai ini. Perahu nelayan juga di sewakan untuk mengunjungi pantai-pantai lain yaitu pantai bolu-bolu, banyu anjlok,klataan, pasir putih.

Namun, pantai lenggoksono masih terlihat kurang bersih karna seringnya dedauanan pohon yang jatuh, kemudian fasilitas seperti tempat duduk belum 
tersedia di pantai ini. Cendramata dan makanan khas juga belum ada untuk dijadikan oleh-oleh dari pantai ini. Dari hasil wawancara kami bersama pak Kasembadan selaku kepala pengawas pantai akan ada pembangunan rumah jaga di pulau gadung yang terkenal sebagai sumber lobster di daerah teluk lenggoksono, tempat ini juga akan dijadikan objek wisata untuk beberapa tahun kedepan.

\section{Pantai Wediawu}

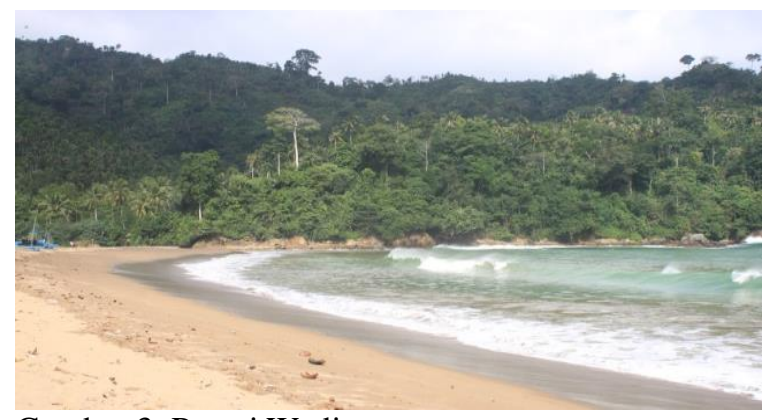

Gambar 3. Pantai Wediawu

Pantai Wedi Awu yang terletak di desa purwodadi tepatnya di dusun Balearjo, untuk mengakses pantai ini melewati tanjakan dan turunan berkelok yang begitu curam. Posisi pantai wedi awu berada di balik perkampungan dusun balerejo dan di apit oleh dua bukit yang memisakannya dengan pantai lenggoksono. Tidak ada pemungutan biaya untuk mengunjungi pantai ini, karena semua biaya untuk mengunjungi pantai ini dan pantai lainnya cukup membayar di loket lenggoksono saja. Pantai ini juga merupakan tempat surfing yang terkenal dengan ombak pantai yang datar dan halus.

Pantai ini sangat mempesona pengunjungnya karena terlihat alami dan bersih. Di bibir pantai juga terdapat banyak pohon kelapa serta perahu nelayan, di sebelah lahan tegalan kelapa terdapat tanah kosong milik desa yang digunakan sebagai lapangan sepak bola. Pada tanggal 16 bulan juli lapangan bola di jadikan sebagai tempat perkemahan para peserta lomba mancing yang di selenggarakan oleh Bupati dan para panitia M3R(Mancing Mania Malang Raya). Titik lomba memancing berada di pantai lenggoksono dan wedi awu. Namun, di pantai ini juga belum ada dijual cindramata serta kiliner yang khas sama dengan kondisi di pantai lenggoksono. Selama melakukan observasi di pantai ini, kami mendapat informasi penting yaitu akan di laksanakan proyek pembuatan jalan untuk mempermudah akses ke pantai.

\section{Pantai Banyu Anjlok}
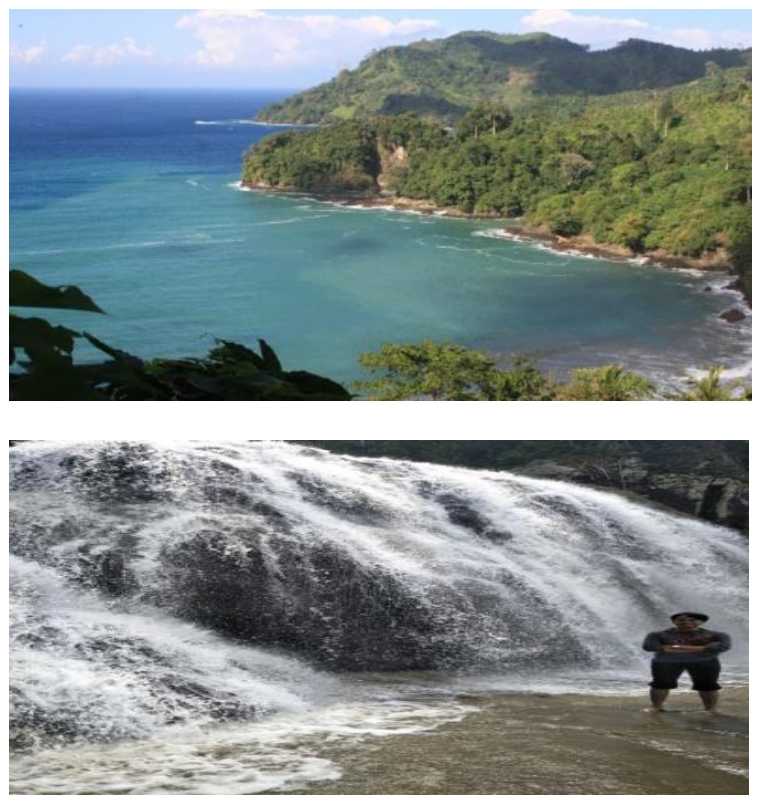

Gambar 3. Pantai Banyu Anjlok

Banyu Anjlok adalah sebuah nama yang di ambil dari bahasa jawa, jika di artikan menjadi bahasa Indonesia ialah air yang jatuh. Pantai banyu anjlok juga berada di desa purwodadi dekat dengan patai lenggoksono jika menggunakan jalur laut dengan menaiki perahu nelayan. Pantai ini akan mempesona pengunjungnya yang datang dengan pemandangan air terjun yang mengalir langsung kearah pantai. Untuk mengunjungi pantai ini juga dapat melalui jalur darat, dengan berjalan kaki sejauh $3 \mathrm{~km}$ atau menggunakan ojek dengan membayar Rp 50.000 . Sangat disayangkan sekali akses darat menuju ke pantai banyu anjlok sangat memprihatinkan, karena kondisi jalan sangat sempit dengan ukuran setengah meter saja dan jalan yang menanjak serta dihiasi oleh jurang karena melalui perbukitan.

\section{Fasilitas Pendukung Pariwisata}

\section{Identifikasi Fasilitas Pendukung Pariwisata}

\section{A. Homestay}

Pada tahap pertama KKN Tematik di Desa Purwodadi, kami juga di tugaskan untuk Mengidentifikasi Fasilitas pendukung pariwisata berupa homestay di Desa Purwodadi. Dengan mempelajari berbagai aspek, seperti tersedianya sarana dan prasarana wilayah desa sekitar yang mendukung perkembangan Homestay, maka kami ingin menganalisis menggunakan analisis SWOT.

Tabel A. Analisis SWOT Homestay

\begin{tabular}{|c|l|cl|}
\hline Fasilitas & Kekuatan & \multicolumn{2}{|c|}{ Kelemahan } \\
\hline HomeStay & $\begin{array}{l}\text { 1. Lingkungan } \\
\text { yang aman }\end{array}$ & 1. & Akomodasi \\
& dan tentram. & & yang masih \\
& 2. Keadaang \\
& HomeStay & 2. & Letak parkir \\
& yang bersih, & & kurang \\
& memadai \\
\hline
\end{tabular}




\begin{tabular}{|l|l|l|} 
drainasenya & 3. & Tidak ada \\
bagus. & penunjuk \\
3. Pemilik & jalan \\
Homestay & 4. & Ada \\
yang ramah. & beberapa \\
& Homestay \\
& yang \\
& Aksesibilitas \\
& masih \\
& kurang baik, \\
& seperti jalan, \\
& letaknya \\
& yang jauh \\
& dari lokasi \\
& wisata dll. \\
&
\end{tabular}

Sumber: Hasil Analisa

\section{B. Cinderamata}

Pada tahap pertama KKN Tematik di Desa Purwodadi, kami juga di tugaskan untuk Mengidentifikasi Fasilitas pendukung pariwisata berupa Cinderamata di Desa Purwodadi. Dengan mempelajari berbagai aspek, seperti tersedianya sarana dan prasarana wilayah desa sekitar yang mendukung perkembangan Cinderamata, maka kami ingin menganalisis menggunakan analisis SWOT.

Tabel B. Analisis SWOT Cinderamata

\begin{tabular}{|c|c|c|}
\hline Fasilitas & Kekuatan & Kelemahan \\
\hline Cinderamata & $\begin{array}{ll}\text { 1. } & \text { Banyak } \\
\text { Sumber } \\
\text { daya alam } \\
\text { yang } \\
\text { tersedia } \\
\text { terutama } \\
\text { kayu } \\
\text { sengon dll. } \\
\text { 2. } \begin{array}{l}\text { Lahan } \\
\text { untuk }\end{array} \\
\text { berjualan } \\
\text { tersedia } \\
\text { banyak } \\
\text { Peluang } \\
\text { penjualan } \\
\text { cinderamat } \\
\text { a yang } \\
\text { lumayan } \\
\text { besar, } \\
\text { mengingat } \\
\text { wisatawan } \\
\text { banyak } \\
\text { yang } \\
\text { mengunjun } \\
\text { gi lokasi } \\
\text { wisata. } \\
\text { Tersediany } \\
\text { a obyek } \\
\text { wisata } \\
\text { yang } \\
\text { banyak. }\end{array}$ & $\begin{array}{ll}\text { 1. } & \text { Kurangnya } \\
\text { Tenaga ahli } \\
\text { pembuat } \\
\text { cinderamat } \\
\text { a. } \\
\text { 2. }\end{array}$ \\
\hline
\end{tabular}

\section{Sumber: Hasil Analisa}

\section{Transportasi Ojek Wisata}

Pada tahap pertama KKN Tematik di Desa Purwodadi, kami juga di tugaskan untuk Mengidentifikasi Fasilitas pendukung pariwisata berupa Transportasi Ojek Wisata di Desa Purwodadi. Dengan mempelajari berbagai aspek, seperti tersedianya sarana dan prasarana wilayah desa sekitar yang mendukung perkembangan Transportasi Ojek Wisata, maka kami ingin menganalisis menggunakan analisis SWOT.

Tabel A. Analisis SWOT Transportasi Ojek Wisata

\begin{tabular}{|c|c|c|}
\hline Fasilitas & Kekuatan & Kelemahan \\
\hline $\begin{array}{l}\text { Transporta } \\
\text { si Ojek } \\
\text { Wisata }\end{array}$ & $\begin{array}{ll}\text { 1. } & \text { Pendapatann } \\
\text { ya per hari } \\
\text { bisa 100k- } \\
\text { 150k/ hari. } \\
\text { 2. } \\
\text { Transportasi } \\
\text { ojek sudah } \\
\text { tertata } \\
\text { dengan baik. }\end{array}$ & $\begin{array}{ll}\text { 1. } & \text { Adanya } \\
\text { perselisiha } \\
\mathrm{n} \text { antara } \\
\text { sesama } \\
\text { transporta } \\
\text { si wisata } \\
\text { berupa } \\
\text { ojek. } \\
\text { 2. } \\
\text { Harganya } \\
\text { yang } \\
\text { mahal. }\end{array}$ \\
\hline
\end{tabular}

Sumber: Hasil Analisa

\section{Kuliner}

Pada tahap pertama KKN Tematik di Desa Purwodadi, kami juga di tugaskan untuk Mengidentifikasi Fasilitas pendukung pariwisata berupa Kuliner di Desa Purwodadi. Dengan mempelajari berbagai aspek, seperti tersedianya sarana dan prasarana wilayah desa sekitar yang mendukung perkembangan Kuliner, maka kami ingin menganalisis menggunakan analisis SWOT.

Tabel A. Analisis SWOT Kuliner

\begin{tabular}{|c|c|c|}
\hline Fasilitas & Kekuatan & Kelemahan \\
\hline Kuliner & $\begin{array}{l}\text { 1. Sumber } \\
\text { daya alam } \\
\text { yang } \\
\text { melimpah } \\
\text { (ikan, } \\
\text { lobster, } \\
\text { udang, } \\
\text { durian, } \\
\text { dll) }\end{array}$ & 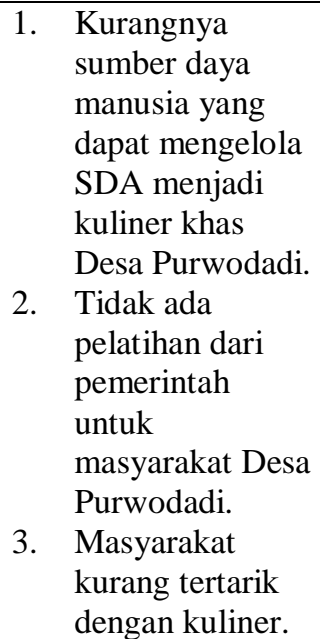 \\
\hline
\end{tabular}

Sumber: Hasil Analisa 


\section{E. TIC (Tourism Information Center)}

Pada tahap pertama KKN Tematik di Desa Purwodadi, kami juga di tugaskan untuk Mengidentifikasi Fasilitas pendukung pariwisata berupa TIC (Tourism Information Center) di Desa Purwodadi. Dengan mempelajari berbagai aspek, seperti tersedianya sarana dan prasarana wilayah desa sekitar yang mendukung perkembangan TIC, maka kami ingin menganalisis menggunakan analisis SWOT.

Tabel E. Analisis SWOT TIC (Tourism Information Center)

\begin{tabular}{|c|c|c|}
\hline Fasilitas & Kekuatan & Kelemahan \\
\hline $\begin{array}{l}\text { Tourism } \\
\text { Information } \\
\text { Center }\end{array}$ & $\begin{array}{ll}\text { 1. } & \text { Sudah } \\
\text { ada } \\
\text { Bangun } \\
\text { an } \\
\text { khusus } \\
\text { untuk } \\
\text { TIC }\end{array}$ & $\begin{array}{ll}\text { 1. } & \begin{array}{l}\text { Gedung TIC } \\
\text { belum } \\
\text { terpakai }\end{array} \\
\text { 2. } & \begin{array}{l}\text { Banyak } \\
\text { lokasi yang } \\
\text { tidak ada } \\
\text { papan } \\
\text { informasiny } \\
\text { a. }\end{array} \\
\text { 3. } & \text { TIC tidak } \\
\text { beroperasi } \\
\text { Alokasi } \\
\text { dana untuk } \\
\text { TIC masih } \\
\text { belum ada. }\end{array}$ \\
\hline
\end{tabular}

Sumber: Hasil Analisa

\section{Kelembagaan Pariwisata Desa}

Desa Purwodadi termasuk desa yang sudah maju dalam hal wisata lautnya, karna daerah ini merupakan daerah perkumpulan dari berbagai desa tetangga ketika mengadakan event lautnya. Untuk melaksanakan segala macam kegiatan tersebut tidaklah mungkin terjadi begitu saja, perlu adanya kerjasama antar masyarakat dan organisasi yang menjadi penyambung, eksekutor, dan pemimpin. Maka dari itu dibuatlah sekumpulan organisasi yang mempu menaungi hal tersebut. Begitu juga dengan desa Prwodadi yang juga didukung kelembagaan pantainya yang terdiri dari 2 kelompok yaitu : POKDARWIS (Kelompok Sadar Wisata), LAGESTA (Lembaga Desa Wisata).

\section{POKDARWIS (Kelompok Sadar Wisata)}

Kelompok Sadar Wisata (POKDARWIS) merupakan komponen dalam tatanan kehidupan masyarakat yang memiliki peran dan kontribusi penting dalam mengembangkan potensi pariwisata di suatu daerah (Rahim, 2012).

Kelompok masyarakat yang tergabung dalam organisasi sadar wisata harus mampu berperan sebagai motivator, penggerak serta komunikator dalam menggali kepedulian masyarakat disekitar destinasi wisata agar setiap destinasi yang memiliki nilai manfaat dapat dikembangkan untuk meningkatkan hajat orang banyak.

Keanggotaan POKDARWIS desa Purwodadi bersifat sukarela yang memiliki dedikasi dan komitmen dalam mengembangkan pariwisata serta memiliki kepedulian. Struktur kepengurusan POKDARWIS terdiri dari Pembina/Pelindung, Penasehat, Pimpinan, Sekretariat, Anggota dan seksi-seksi.

\section{LADESTA (Lembaga Desa Wisata)}

3. POKMASWAS (Kelompok Masyarakat Pengawas)

POKMASWAS adalah kelompok yang berperan sebagai pengawas zona wisata pada suatu daerah. Di desa Purwodadi kelompok ini diketuai oleh Bapak Kasembadan yang mana merupakan ketua POKMASWAS Malang Selatan.

POKMASWAS didesa Purwodadi sendiri bekerja menangani berbagai masalah yang terkait dengan pantai, dari masalah illegal fishing, penjaringan ikan dengan bahan peledak, budidaya lobster, pembentukan terumbu karang dan masih banyak lagi. Untuk rencana kedepannya POKMASWAS dan masyarakat akan membangun rumah penjaga di pantai Gadung. Pantai Gadung adalah pantai yang digunakan untuk bududaya lobster sedangkan rencana selanjutnya POKMASWAS akan membangun rumah apung dipantai bolu bolu.

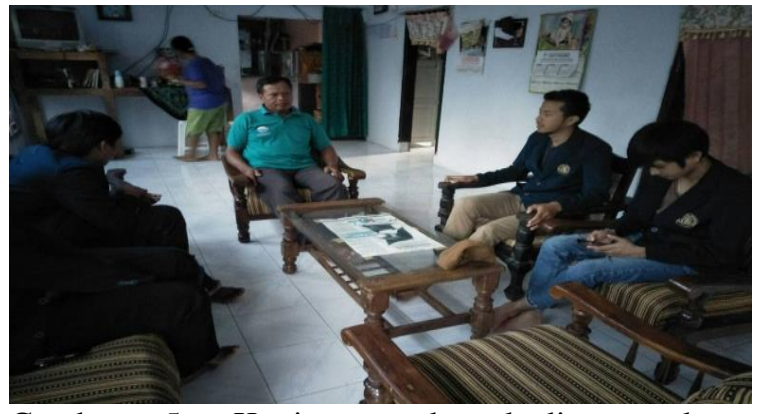

Gambar 5. Kunjungan ke kediaman ketua POKMASWA

\section{KESIMPULAN}

Kesimpulan yang dapat diambil yaitu potensi pada Desa Purwodadi sudah sesuai apabila akan dikembangkan menjadi desa wisata dan desa agrowisata karena memiliki potensi yang baik. Kurang pengembangan yang lebih baik lagi apabila ingin menjadikan desa ini menjadi Desa Wisata bertaraf nasional.

\section{UCAPAN TERIMAKASIH}

Ucapan terimakasih diberikan kepada Kementerian Ristek Dikti selaku penyokong dana dalam program pengabdian kepada masyarakat ini dalam program KKN-PPM (Kuliah Kerja Nyata-Pembelajaran dan Pemberdayaan Masyarakat). 